\title{
The development of state/region owned goods management's monitoring instrument design
}

\author{
Yogy Ikhwanto ${ }^{1}$, and Irwan Taufiq Ritonga ${ }^{2}$ \\ ${ }^{1}$ Fellowship of Magister of Accounting, Universitas Gadjah Mada, Yogyakarta, Indonesia \\ ${ }^{2}$ Lecturer at Magister of Accounting, Universitas Gadjah Mada, Yogyakarta, Indonesia
}

\begin{abstract}
The problems in state/region owned goods in Indonesian state and local governments are suspected to occur because of weak monitoring programs, according to many studies. A tool or instrument in implementing this monitoring program is expected to address this problem. Such tool currently doesn't exist yet. This research aims to fill that gap by developing a monitoring instrument design for state/region owned goods by using Daerah Istimewa Yogyakarta (DIY) Local Government as a research context in order to take valuable inputs for the design. This research is using developmental research method. Government Regulation were used for normative reference and Friedman's results-based accountability quadrat were used in developing good indicators for the instrument. This research is succeeded in formulating the indicators that made up the instrument. Indicators compiled are divided into compliancebased indicators and results-based indicators. Indicators are formulated based on the validation and inputs from employees of DIY's Assets Management Agency and experts from academia. This instrument still has some limitations that need improvement through further research.
\end{abstract}

\section{Introduction}

Problematic management of state or region owned goods (SOG/ROG) is still being a major issue for many governmental entities in Indonesia. The impact of the problem can be seen in the financial statement's opinion obtained because of the ties between the SOG/ROG's management and accounting. Proven as an example, Biannually Inspection Summary I of Year 2015 of Republic of Indonesia's Audit Board (BPK RI) indicated as many as 230 financial statements of local governments obtained qualified/disclaimer of opinion from fixed asset accounts and/or other assets, as well as 37 from the inventory account [1].

Several studies have tried to examine the causes of the problems in managing SOG/ROG in the context of different local governments. Fatana [2] conducted a research of ROG problem in Lombok Barat regency and found that weaknesses in the administration of ROG were caused in part by the lack of ROG management monitoring program. Other research that focused on the management of the fixed assets as a form of ROG found positive and significant relationship between monitoring and controlling program with fixed asset optimality [3-4].

If SOG/ROG monitoring program is so important, then how to make sure that the 
monitoring program as mandated by Government Regulation No. 27 Year 2014 about State/Local Government's Goods Management effectively improve the quality SOG/ROG management? Based on good practices, a monitoring and/or evaluation program are not only a means to look at the suitability of the activities with the regulations, but also to measure the achievement of results through performance indicators [5]. To achieve these objectives, an instrument that contains a list of questions or indicators of performance is commonly used as practiced by various local and international entities. The existence of such instruments is believed by many organizations to be effectively assisting the implementation of monitoring and evaluation of programs.

As best as the author searched, such monitoring instrument doesn't exist yet for SOG/ROG management, whether published officially or developed academically (no previous research). Knowing the importance of monitoring and evaluation as well as the condition of vacant monitoring instruments related to the SOG/ROG management as stated above, then it is required to conduct a developmental research to produce an instrument or a tool to implement the mandate of monitoring the SOG/ROG management stipulated in Government Regulation No. 27 of 2014 which is capable of monitoring the implementation, performance, and the results of SOG/ROG management. Hopefully such instrument can improve the effectiveness of the monitoring program. To achieve this objective, a model or framework that is practical, but also results-based in its development is needed. Therefore, the development of SOG/ROG management's monitoring instrument design that is practical and results-based will be the goal of this research.

\section{Literature review}

\subsection{The management of SOG/ROG}

The legal basis for the SOG/ROG management is Government Regulation No. 27 Year 2014 on the Management of State and Region Owned Goods. Based on Government Regulation No. 27 Year 2014, the management of SOG/ROG includes the management stages as follows: needs planning, procurement, usage, utilization, security and maintenance, valuation, deletion, transfer, extermination, administration, guidance, supervision, and control.

Author could not find a specific previous research similar to that conducted in this research because this research is using developmental research method that is rarely used. A similar research method with a different topic conducted by Muktiali [6] who developed the instrument of monitoring and evaluation of development outcomes in Semarang City.

SOG/ROG management also has close links with the accounting. Issuance of Government Regulation No. 27 of 2014 set the various provisions related to the management of SOG/ROG that contribute to government accounting [7]. Determination of the status of use by a decree is a basis for accounting records. Administration in general gives evidence for the accounting records like proof of purchase, proof of transfer, and evidence of removal. In addition, the regulation also concerns the assessment of land and buildings in case of utilization and transfer to get fair value which is in accordance with good accounting practices internationally.

In addition, there is also an obligation in applying accounting policies depreciation of fixed assets in 2015. This obligation provides an opportunity to measure the performance of government fixed asset management using depreciation account. In particular, when the entity applying good management of fixed assets, the entity will report accumulated depreciation that is lower compared with entities that do not manage their fixed assets as well [8]. This is because the entity maintained its fixed assets in good condition through maintenance. Moreover, because of the nature of the depreciation of fixed assets itself that 
provides an indicator of the power serviceability fixed assets to the government or the public [9].

\subsection{Monitoring and evaluation}

Monitoring is an internal activity that is designed to provide regular feedback on the progress of a program, the problems encountered, the efficiency of program implementation and achievement of program outcomes [10]. This definition is consistent with the intent of monitoring in Government Regulation No. 39 of 2006 Article 1 paragraph 2. Meanwhile, the evaluation is an activity to systematically and objectively measure how well a program is achieving the desired objectives and how far the changes can be attributed to the program [11].

There are many monitoring and evalution frameworks well-known in the world. For present study, the author chose to use results-based accountability (RBA) framework developed by Friedman [12]. The RBA is more appropriately used as a monitoring and evaluation framework in administrative activities such as SOG/ROG management compared to other framework. The framework can be seen in the figure below.

\begin{tabular}{|c|c|c|}
\hline & Quantity & Quality \\
\hline 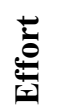 & $\begin{array}{l}\text { (1) What did we do } \\
\text { (\#) }\end{array}$ & $\begin{array}{c}\text { (2) How well did we do it } \\
(\%)\end{array}$ \\
\hline 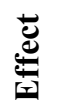 & $\begin{array}{c}\text { (3) Is anything better off? } \\
\text { (\# output) }\end{array}$ & $\begin{array}{c}\text { (4) Is anything better off } \\
\text { (\% outcomes) }\end{array}$ \\
\hline
\end{tabular}

\section{Figure 1. Friedman's results-based accountability framework}

Friedman grouped all performance indicators in the world into four categories pictured in quadrants as shown in the figure above. Most effective performance indicator that can drive real change and outcomes are in quadrant number 2 or $2^{\text {nd }}$ quadrant, which are performance quality indicators, and quadrant number 4 or $4^{\text {th }}$ quadrant which are outcome quality indicators. Indicators for the instrument designed must be formulated to meet the criteris in this two categories.

\section{Research method}

The authors chose the Local Government Special Region of Yogyakarta (DIY) as a research context to undertake preliminary research and validation test of the monitoring instrument developed.

The author used a developmental research approach for this research. Developmental research can easily be interpreted as a study that aims to produce or develop a product [13]. However, a more complete definition of a developmental research is also a research that provides a way to apply theory, validate the good practice that is already running, and develop a procedure, technique, or a new instrument based on the analysis of a particular case [14]. The research's process framework can be pictured in the figure below. 


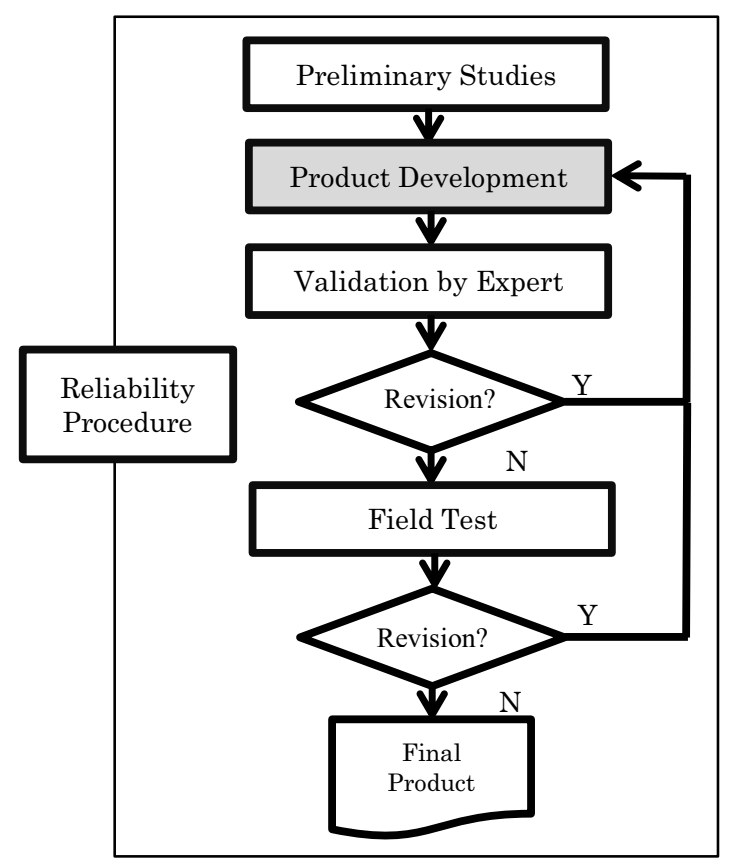

Figure 2. Research's Process Framework

In general, the series of activities in developmental research can be explained as follows:

a. Preliminary studies, consisting of literature studies and field studies. Literature studies aim to find a model that suits procedural formulation of the problem. The field study is conducted to assess the needs, understand the process, and understand the contextual conditions in which the product will be implemented. The field study will be conducted with a qualitative approach through in-depth interviews and focus group discussion.

b. The product development stage. Friedman's result-based quadrant [15] is used to help to determine the class of the the performance indicators developed in the instruments.

c. Expert's Validation stage, namely the involvement stage of experts associated with the products developed to determine whether the products developed by the research were ready to be applied in the field.

d. The pilot phase, which is a stage to evaluate the usability of the product on a limited basis in the context of the research (Government of DIY). Limited test will be done by monitoring the performance of ROG management at the governmental unit (satuan kerja perangkat daerah) in DIY using instruments that have been developed.

e. Procedure of reliability, which is to document all the procedures described above well enough so that if other researchers perform the same procedure on the same case it will get the same findings and conclusions, as described by Yin [16] concerning the reliability in qualitative research.

\section{Results and discussion}

This research succeeded in formulating a set of indicators that make up the instrument in monitoring ROG management in local government of DIY through the development stage by the author and validation by experts. The instrument developed also have passed the pilot phase to determine the usability of the indicators in the context of research with the available data. 
The Summary of compiled performance indicators that make up the ROG management's monitoring instruments can be presented in the following table.

Table 1. Summary of Performance Indicators in ROG Management's Monitoring Instrument

\begin{tabular}{|c|c|c|}
\hline No & Performance Indicators & Scoring \\
\hline \multicolumn{3}{|c|}{ Compliance Monitoring Indicators } \\
\hline \multicolumn{3}{|c|}{ Stage: Needs and budget planning } \\
\hline 1. & $\begin{array}{l}\text { Timely submission of proposals of ROG needs } \\
\text { (including procurement, maintenance, usage, removal, } \\
\text { and extermination) }\end{array}$ & $\begin{array}{r}\text { Timely }=1 \\
\text { Late }=0\end{array}$ \\
\hline 2. & $\begin{array}{l}\text { The suitability of the proposed ROG needs to the } \\
\text { standard (including items standards and price } \\
\text { standards) }\end{array}$ & $\begin{aligned} \text { Conformed } & =1 \\
\text { Not conformed } & =0\end{aligned}$ \\
\hline 3. & $\begin{array}{l}\text { Completeness and correctness of information in ROG } \\
\text { needs proposal }\end{array}$ & $\begin{array}{r}\text { conformed criteria/ } \\
\Sigma \text { criteria }\end{array}$ \\
\hline \multicolumn{3}{|c|}{ Stage: Procurement } \\
\hline 4. & Timely submission on procurement report & $\begin{array}{r}\text { Timely }=1 \\
\text { Late }=0\end{array}$ \\
\hline 5. & Completeness of information in procurement report & $\begin{array}{r}\Sigma \text { conformed criteria/ } \\
\Sigma \text { criteria }\end{array}$ \\
\hline 6. & $\begin{array}{l}\text { Compliance of realization in types and quantities of } \\
\text { procurement against it's budget }\end{array}$ & $\begin{array}{r}\text { Conformed }=1 \\
\text { Not conformed }=0\end{array}$ \\
\hline \multirow[t]{2}{*}{7.} & Timely procurement based on cash flow predictions & $\begin{array}{r}91 \%-100 \% \text { Conformed }=1 \\
71 \%-90 \% \text { Conformed }=0,75 \\
51-70 \% \text { Conformed }=0,50 \\
21-50 \% \text { Conformed }=0,25 \\
<20 \% \text { Conformed }=0\end{array}$ \\
\hline & $\begin{array}{l}\begin{array}{l}\text { Availability of acceptable excuse for untimely } \\
\text { procurement }\end{array} \\
\end{array}$ & $\begin{array}{r}\text { Acceptable: } 1-\text { (score above) } \\
\text { Not Acceptable: } 0\end{array}$ \\
\hline \multicolumn{3}{|c|}{ Stage: Security and Maintenance } \\
\hline 8. & Timely submission of maintenance report & $\begin{array}{r}\text { Timely }=1 \\
\text { Late }=0\end{array}$ \\
\hline \multirow[t]{2}{*}{9.} & $\begin{array}{l}\text { Compliance of budget and performance target in } \\
\text { maintenance realization }\end{array}$ & $\begin{array}{r}91 \%-100 \% \text { Conformed }=1 \\
71 \%-90 \% \text { Conformed }=0,75 \\
51-70 \% \text { Conformed }=0,50 \\
21-50 \% \text { Conformed }=0,25 \\
<20 \% \text { Conformed }=0\end{array}$ \\
\hline & $\begin{array}{l}\text { Availability of acceptable excuse for unconformed } \\
\text { maintenance realization }\end{array}$ & $\begin{array}{r}\text { Acceptable: } 1-(\text { score above }) \\
\text { Not Acceptable: } 0 \\
\end{array}$ \\
\hline 10. & $\begin{array}{l}\text { Quality of physical, administrative, and legal security } \\
\text { of assets }\end{array}$ & $\begin{array}{r}\Sigma \text { conformed criteria/ } \\
\Sigma \text { criteria }\end{array}$ \\
\hline \multicolumn{3}{|c|}{ Stage: Administration } \\
\hline 11. & $\begin{array}{l}\text { Conformity of bookkeeping with the status decalred for } \\
\text { the ROG }\end{array}$ & $\begin{aligned} \text { Conformed } & =1 \\
\text { Not conformed } & =0\end{aligned}$ \\
\hline 12. & $\begin{array}{l}\text { Conformity of room and unit inventory book with the } \\
\text { main inventory book }\end{array}$ & $\begin{aligned} \text { Conformed } & =1 \\
\text { Not conformed } & =0\end{aligned}$ \\
\hline 13. & Conformity of five-yearly inventarization & $\begin{aligned} \text { Conformed } & =1 \\
\text { Not conformed } & =0\end{aligned}$ \\
\hline 14. & $\begin{array}{l}\text { Conformity of yearly inventarization for supplies and } \\
\text { inventories }\end{array}$ & $\begin{aligned} \text { Conformed } & =1 \\
\text { Not conformed } & =0\end{aligned}$ \\
\hline 15. & Conformity of installation of ownership sign & $\begin{aligned} \text { Conformed } & =1 \\
\text { Not conformed } & =0\end{aligned}$ \\
\hline 16. & Timely reconciliation of ROG & $\begin{aligned} \text { Conformed } & =1 \\
\text { Not conformed } & =0\end{aligned}$ \\
\hline 17. & $\begin{array}{l}\text { Conformity of depreciation calculation with the } \\
\text { accounting policy }\end{array}$ & $\begin{aligned} \text { Conformed } & =1 \\
\text { Not conformed } & =0\end{aligned}$ \\
\hline
\end{tabular}




\begin{tabular}{|c|l|r|}
\hline No & Performance Indicators & Scoring \\
\hline Stage: General condition & According to the results \\
\hline 18. & $\begin{array}{l}\text { The ratio of active inventory items used to total } \\
\text { inventory }\end{array}$ & According to the results \\
\hline 19. & $\begin{array}{l}\text { The ratio of the value of inventory items in good } \\
\text { condition to total value of inventory }\end{array}$ & According to the results \\
\hline 20. & $\begin{array}{l}\text { The ratio of maintenance expenditures to depreciation } \\
\text { expense }\end{array}$ &
\end{tabular}

Source: Developed.

Based on its characteristics, the author divided the indicators developed into two categories, namely compliance-based indicators that belong to $2^{\text {nd }}$ quadrant of Friedman's RBA and indicators of the quality of ROG management work in general that belong to $4^{\text {th }}$ quadrant of results-based indicators according to Friedman's. Limited pilot phase of the indicators above has also been conducted in The Government of DIY. However, the evaluation of indicators of general condition of ROG management cannot be done at the moment because of unavailability of rule of thumb value and therefore become the limitation of this instrument.

Indicators that measure the ROG management conditions in general require a separate study to determine the rules of thumb value that can be empirically proven. Studies can be done by measuring this indicator within a certain time on a variety of government entities that are considered good in managing SOG and/or ROG based on the indicators of compliance offered in the instrument. With proper statistical procedure, a particular rule of thumb value can be obtained.

The current instrument have not set the weight of each indicator in order to do the sums to get the value of the final performance indicators. This weighting can be highly subjective because of different perceptions of individuals. To determine the weight in empirical basis, it is necessary to study the perception of many people involved in the management of SOG and/or ROG.

The use of depreciation account of fixed assets as a component of performance indicators still leaves a note for the application of the depreciation policy of fixed assets in Indonesia is still not in good practice. Most government entities are still using the straightline method to calculate the depreciation of fixed assets in all types of assets while the Government Accounting Standard No. 7 paragraph 57 allows the use of other methods. This could result in the record of depreciation that is not conformed with the actual assets' value decrease. A study that aims to determine the appropriate depreciation method that is conformed with the characteristics of each type of government's fixed assets is expected to help address this deficiency.

\section{Conclusions and suggestions}

This research succeeded in formulating a set of indicators that make up the instrument in monitoring ROG management in local government of DIY through the development stage by the author, validation by experts, and limited pilot phase. Based on its characteristics, the author divided the indicators developed into two categories, namely compliance-based indicators and indicators of the quality of ROG management work in general that belong to results-based indicators. Based on the discussion presented in the previous chapter, we can conclude some limitations in the research as well as the advice for conducting the next research as follows.

a. Indicators that measure the ROG management conditions in general require a separate 
study to determine the rules of thumb value that can be empirically proven. Studies can be done by measuring this indicator within a certain time on a variety of government entities that are considered good in managing SOG and/or ROG based on the indicators of compliance offered in the instrument. With proper statistical procedure, a particular rule of thumb value can be obtained.

b. The current instrument have not set the weight of each indicator in order to do the sums to get the value of the final performance indicators. This weighting can be highly subjective because of different perceptions of individuals. To determine the weight in empirical basis, it is necessary to study the perception of many people involved in the management of SOG and/or ROG.

c. The use of depreciation account of fixed assets as a component of performance indicators still leaves a note for the application of the depreciation policy of fixed assets in Indonesia is still not in good practice. A study that aims to determine the appropriate depreciation method that is conformed with the characteristics of each type of government's fixed assets is expected to help address this deficiency. 


\section{References}

1. Badan Pemeriksa Keuangan RI, Ikhtisar Hasil Pemeriksaan Semester I BPK RI Tahun 2015, (2015)

2. D. Fatana, Evaluasi Sistem Pengendalian Internal Pengelolaan Barang Milik Daerah (Unpublished Thesis, 2015)

3. E.B. Bles, Analisis Faktor-Faktor Yang Mempengaruhi Pengelolaan Aset Tetap (Tanah Dan Bangunan): Studi Pada Pemerintah Daerah Kota Jayapura (Unpublished Thesis, 2015)

4. Jusmin, Pengaruh Manajemen Aset Terhadap Tingkat Optimalitas Aset Tetap (Tanah Dan Bangunan) Pemerintah Kota Baubau (Unpublished Thesis, 2015)

5. UNDP, Handbook on Monitoring and Evaluating for Results (2002)

6. M. Muktiali, Jur. RIPTEK Bap. Kot. Sem., Penyusunan Instrumen Monitoring Dan Evaluasi Manfaat Program Pembangunan Di Kota Semarang, 3.2, 11-20 (2009)

7. J. Hoesada, M. Ling, Barang Milik Negara/Daerah (2014)

8. D. Edgerton, Valuation and Depreciation: A Guide for Not-for-Profit and Public Sector under Accrual Based Accounting Standards (2013)

9. J. Hoesada, Dua Puluh Lima Alasan Penyusutan Aset Tetap Dalam Akuntansi Pemerintahan (2007)

10. M. Bamberger, E. Hewitt, Monitoring and Evaluating Urban Development Programs (1986)

11. N. Frankel, A. Gage, M\&E Fundamentals A Self Guided Minicourse (2007)

12. M. Friedman, Trying Hard Is Not Good Enough: How to Produce Measurable Improvements for Customers and Communities, 4th (2005)

13. S. Kantun, Hakikat Dan Prosedur Penelitian Pengembangan (2013)

14. R.C. Richey, J.D. Klein, Jou. Of. Comp. In Hig. Ed., Developmental Research Methods: Creating Knowledge from Instructional Design and Development Practice, 16.2, 23-38 (2005)

15. M. Friedman, Trying Hard Is Not Good Enough: How to Produce Measurable Improvements for Customers and Communities, 4th (2005)

16. R.K. Yin, Case Study Research: Design and Methods, 4th (2014) 